\title{
Is Component Separation a Safe Method in Incisional Hernias?
}

\section{İnsizyonel Hernilerde Komponent Seperasyon Tekniği Güvenli Bir Yöntem midir?}

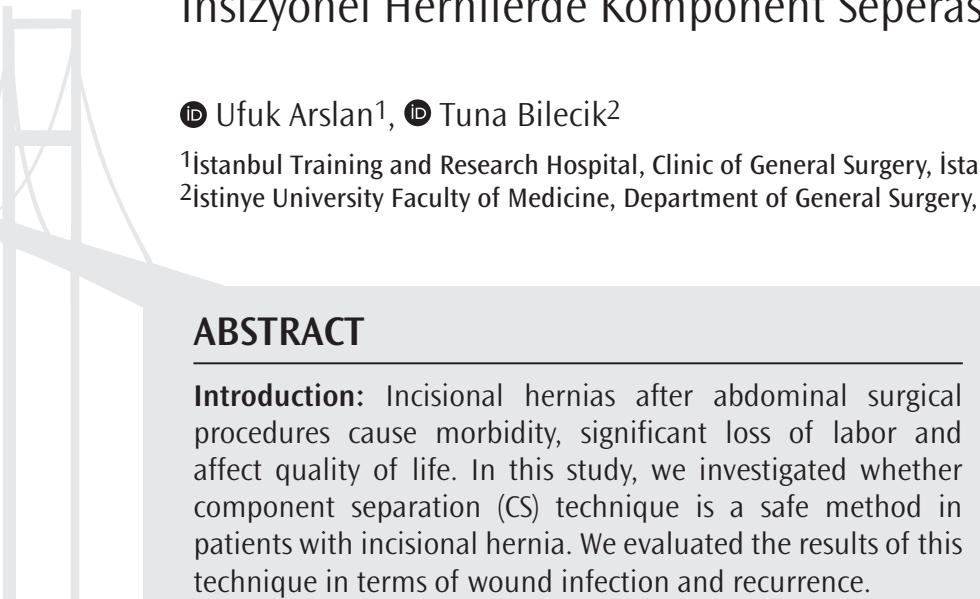

Methods: Thirty incisional hernia cases operated with CS technique between February 2012 and February 2014 were included in the study. Demographic data, body mass index (BMI), American Society of Anesthesiologists (ASA) score, defect size, wound complications and recurrences after one-year follow-up were evaluated.

Results: Seventeen patients were female and 13 were male. The mean age of the patients was 54.8 years (range: $29-76)$. The mean BMI of the patients was $26.8 \mathrm{~kg} / \mathrm{m}^{2}$ (range: $20.5-32.9$ ). The mean hernia transverse diameter was $9.6 \mathrm{~cm}$ (range: $6.5-$ 23). Mortality was not observed in any of the patients. Wound problems were observed in six of 30 patients in CS repair, and recurrence was observed in three of these patients. Recurrence was observed in only one of the remaining 24 patients without a wound problem. Recurrence was found to be statistically related to wound problem. There was also a significant relationship between BMI, hernia transverse diameter, ASA score and recurrence.

Conclusion: In selected cases, CS technique is a safe technique for incisional hernia repair. It can be performed by paying attention to wound problems.
\end{abstract}

Keywords: Component separation, wound infection,

\section{öz}

Amaç: Abdominal cerrahi girișimler sonrasında ortaya çıkan insizyonel herniler önemli oranda işgücü kaybına, morbiditeye neden olur, yaşam kalitesini etkiler. Bu çalışmada insizyonel hernili hastalarda Komponent Seperasyon (KS) tekniğinin güvenli bir yöntem olup olmadığını araştırdık. Bu tekniğin; yara yeri enfeksiyonu ve nüks açısından sonuçlarını değerlendirdik.

Yöntemler: Şubat 2012- Şubat 2014 tarihleri arasında hastanemizde KS tekniği ile ameliyat edilen 30 insizyonel herni olgusu çalışmaya dahil edildi. Hastaların demografik bilgileri, vücut kitle indeksi (VKi), Amerikan Anesteziyoloji Derneği (ASA) skoru, defektin boyu, yara komplikasyonları ve bir yıllık takip sonrası nüksler değerlendirildi.

Bulgular: Hastaların 17'si kadın, 13’ü erkekti. Hastaların yaş ortalaması 54,8 (29-76) idi. Hastaların VKi ortalaması 26,8 kg/ $\mathrm{m}^{2}(20,5-32,9)$ idi. Bu hastaların ortalama fıtık transvers çapı 9,6 cm (6,5-23) idi. Hastaların hiçbirinde mortalite izlenmedi.

KS onarımında 30 hastanın altısında yara yeri problemleri gözlenirken bu hastaların üçünde nüks gözlendi. Yara yeri problemi olmayan 24 olgunun ise sadece birinde nüks gözlendi. Yara yeri problemi olan hastalarda nüks istatistiksel olarak ilișkili bulundu. VKi, fıtık transvers çapı yüksekliği ve ASA skoru ile de nüks arasında anlamlı ilişki saptandı.

Sonuç: Insizyonel herni onarımında uygun olgularda komponent separasyon tekniği güvenli bir tekniktir. Yara problemlerine dikkat edilerek uygulanabilir.

Anahtar Kelimeler: Komponent seperasyon, yara yeri enfeksiyonu, rekürrens

\section{Introduction}

The incidence of incisional hernias (IHs) after median incisions is between $2-11 \%$, with a recurrence rate of $30-50 \%$ after primary repair of IH (1). The incidence of hernia is smaller in small incisions. IHs cause significant labor loss, morbidity and even mortality $(2,3)$. They continue to constitute one of the major problems of surgery due to their frequent incidence and high morbidity. The only treatment option for IHs is surgery. Treatment of IHs includes primary repair and repair with prosthetic materials. Prosthetic material application is the primary option when there is not enough intact tissue (4). Component separation (CS) is based on a functional abdominal wall-shaping concept using autologous tissue (5). The use of patient's own tissues is an advantageous method as it 
reduces the cost compared to meshed repair. The likelihood of a foreign body reaction is thus reduced.

Etiologic factors in IH formation can be classified as modifiable and non-modifiable. Modifiable etiologic factors include obesity, incision pattern, suture material used and wound infection. Non-modifiable etiologic factors include age of the patient, general body weakness and other chronic diseases [chronic obstructive pulmonary disease (COPD), malignancy, prostatism, etc.] of the patient (6-8). CS technique was first described by Ramirez et al. (9) in 1990.

The aim of this retrospective study was to investigate the recurrence, wound complications and general complications of patients who were diagnosed with $\mathrm{IH}$ and operated by CS technique, and to compare these rates with the literature.

\section{Methods}

This study was started after the approval of the İstanbul Okmeydanı Training and Research Hospital Ethics Committee (decision no: 48670771-514.10). This was a clinical retrospective study. Informed consent was obtained from all patients.

Thirty cases of IH operated by CS technique in our hospital between February 2012 and February 2014 were included in the study. The criteria for inclusion in the study were patients older than 18 years, patients with an abdominal midline $\mathrm{IH}$ and patients with transverse diameter of the fascia defect greater than $5 \mathrm{~cm}$. Age, gender, body mass index (BMI), transverse diameter of hernia, and American Society of Anesthesiologists (ASA) score were recorded. Wound infections and recurrences after 1-year follow-up were noted. Table 1 shows the demographic characteristics and recorded physical examination findings of the operated patients.

All patients received $1 \mathrm{~g}$ of first generation cephalosporin (ibrahim Etemmenarini, İstanbul, Turkey) one hour prior to surgery. The operations were performed under general anesthesia in supine position. Second generation cephalosporin (Nobel, İstanbul, Turkey) was given orally for 5 days after surgery. A urinary catheter was inserted during the surgery. Two subcutaneous aspirating drains were routinely inserted in each patient. 10\% povidone iodine was used as skin antiseptic. Each patient was dressed with antiembolic socks and embolism prophylaxis was performed with low molecular weight heparin (Sanofi-aventis, İstanbul, Turkey) in patients with a BMI over 30 .

Following the preparations described above, the skin is opened with a midline incision to include the previous incision scar. The intestines and other organs are dissected from the ventral abdominal wall (Figure 1). In this way, the lateral border of the rectus abdominis muscle can be accurately recognized through the abdomen. The skin and subcutaneous tissue are dissected from anterior rectus sheath and external oblique aponeurosis $5 \mathrm{~cm}$ lateral to the rectus sheath. As the perforating branches of the epigastric artery are cut, blood supply to the skin is at risk. Because the blood supply is then only dependent

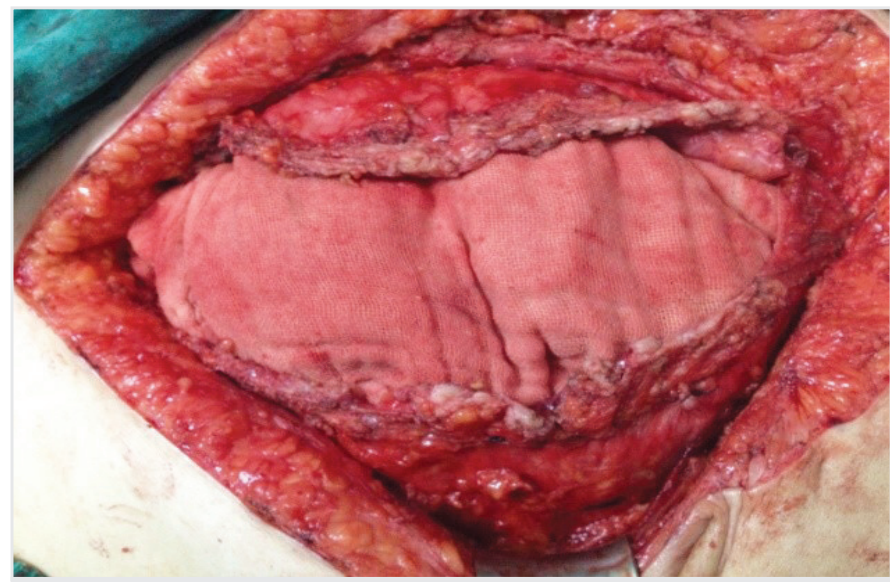

Figure 1. Dissected view of hernia sac, intestines and other organs from ventral abdominal Wall

Table 1. Demographic characteristics and physical examination findings of operated patients

\begin{tabular}{|c|c|c|c|c|}
\hline Features & Patient group $(n=30)$ & n & $\%$ & Mean \pm SD \\
\hline \multirow{2}{*}{ Gender } & Female & 17 & 56.7 & \multirow{2}{*}{$1.433 \pm 0.504$} \\
\hline & Male & 13 & 43.3 & \\
\hline \multirow{3}{*}{ Age (WHO) } & Young (18-65 years) & 24 & 80.0 & \multirow{3}{*}{$3.10 \pm 0.844$} \\
\hline & Middle-aged (66-79 years) & 6 & 20.0 & \\
\hline & Elderly (80-99 years) & 0 & 0 & \\
\hline \multirow{4}{*}{ BMI } & Underweight $\left(<18.5 \mathrm{~kg} / \mathrm{m}^{2}\right)$ & 0 & 0 & \multirow{4}{*}{$1.70 \pm 0.876$} \\
\hline & Normal $\left(18.5-24.9 \mathrm{~kg} / \mathrm{m}^{2}\right)$ & 7 & 23.3 & \\
\hline & Overweight $\left(25-29.9 \mathrm{~kg} / \mathrm{m}^{2}\right)$ & 20 & 66.7 & \\
\hline & Obese $\left(30-34.9 \mathrm{~kg} / \mathrm{m}^{2}\right)$ & 3 & 10.0 & \\
\hline \multirow{4}{*}{ ASA score } & ASA 1 & 15 & 50.0 & \multirow{3}{*}{$1.30 \pm 0.651$} \\
\hline & ASA 2 & 11 & 36.7 & \\
\hline & ASA 3 & 2 & 6.7 & \\
\hline & ASA 4 & 2 & 6.7 & \multirow{4}{*}{$1.30 \pm 0.65$} \\
\hline \multirow{3}{*}{ HTD } & Small $(6-10 \mathrm{~cm})$ & 24 & 80.0 & \\
\hline & Medium $(11-14 \mathrm{~cm})$ & 3 & 10.0 & \\
\hline & Large $(>15 \mathrm{~cm})$ & 3 & 10.0 & \\
\hline
\end{tabular}


on the intercostal arteries and the branches of the pudendal artery. In this case, the epigastric perforating vessels should be preserved. The aponeurosis of the external oblique muscle is incised $1-2 \mathrm{~cm}$ lateral to the rectus abdominis muscle. If the incision in the aponeurosis is made correctly, fatty cell tissue is exposed. If the muscle is seen, the incision is not in the right place. The myoaponeurosis of the external oblique muscle is transected longitudinally along its length. Seven to

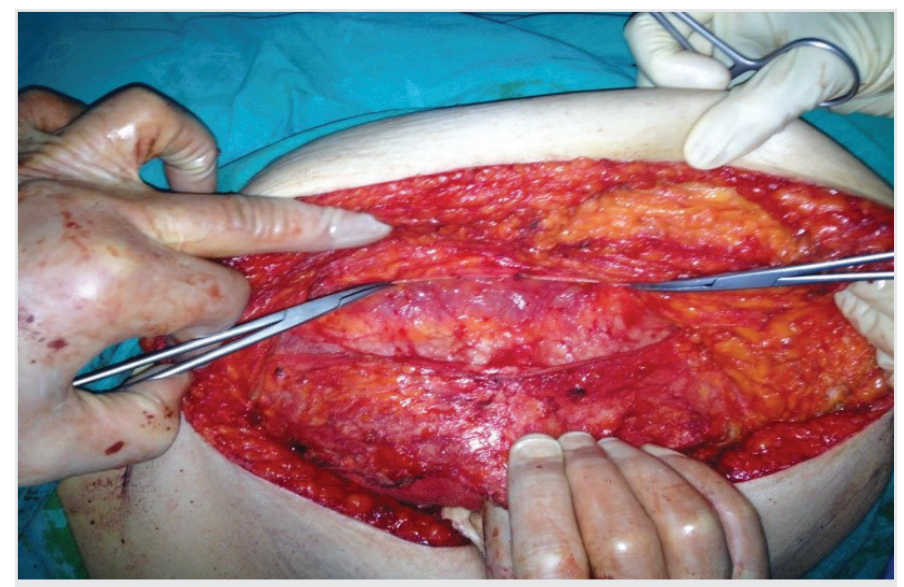

Figure 2. Longitudinal excision of external oblique aponeurosis

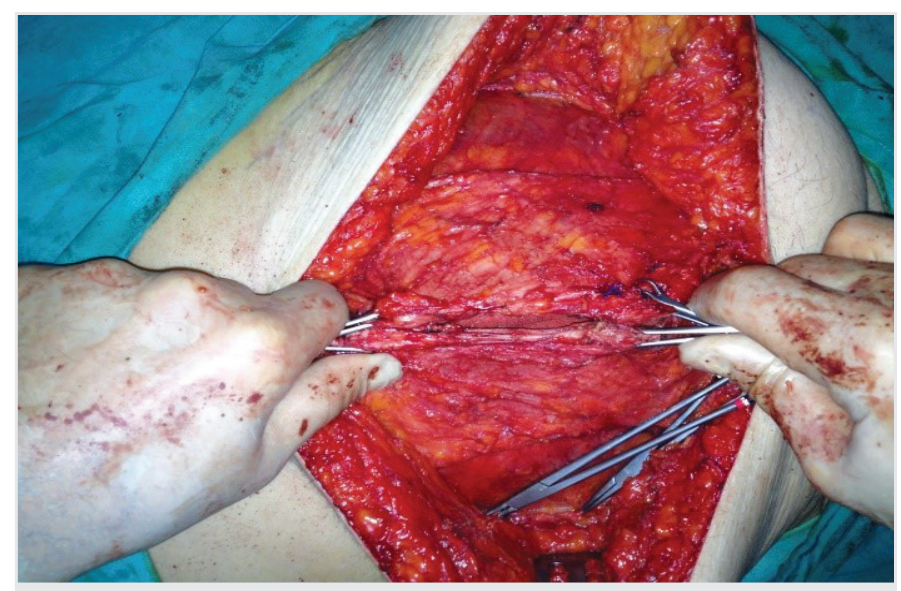

Figure 3. Completed version of bilateral separation ten $\mathrm{cm}$ muscular part of the external oblique muscle in the thorax wall extending cranially is added to the transection. With this extension, the rectus abdominis muscle can be maximally medially rotated in the upper abdomen. Connections to the ribs should be dissected to fully mobilize the rectus abdominis muscle. The external oblique muscle is separated from the internal oblique muscle up to the midaxillary line using the avascular plane between the two muscles. This mobilization is very important, since fibrous connections between the muscles will prevent optimal medial displacement of the rectus abdominis muscle. It is very important to determine the plane between the internal and external oblique muscles correctly. Transection of the internal oblique muscle may lead to abdominal wall rupture, because the transverse abdominal muscle is too weak to withstand intraabdominal pressure. In addition, neurovascular structures can be easily damaged as they lie between the internal oblique and transverse abdominal muscles. As a result, the abdominal wall muscles are denervated. With this technique, rectus muscle can be advanced unilaterally $3-5 \mathrm{~cm}$ on the upper edge, $7-10 \mathrm{~cm}$ in the waistline, and $1-3 \mathrm{~cm}$ in the lower abdomen (Figure 2). An additional 2-4 cm advance can be achieved by separating the posterior sheath of the rectus abdominis muscle. The posterior sheath is incised along its entire length close to the midline. The rectus abdominis muscle is easily separated from the posterior rectus sheath. The abdominal wall is sutured continuously in the midline with non-absorbable or slowabsorbing sutures through the fascia. The suture length should be at least 4 times the wound in the fascia. Drains are placed under the skin. Defects up to $28 \mathrm{~cm}$ at waist level can be closed in this way (Figure 3).

\section{Statistical Analysis}

The findings of the study were analyzed with SPSS 13.0. Descriptive statistics (mean, standard deviation) were used in the evaluation of qualitative data. $X^{2}$ test was used for comparison of qualitative data. Student's t-test was used to analyze the quantitative data. The results were evaluated with 95\% confidence interval and level of significance was $p<0.05$.

\section{Results}

Thirty patients were operated with this technique. The mean transverse diameter of hernia was $9.6 \mathrm{~cm}$ (range: $6.5-23$ ). Seventeen patients were

\section{Table 2. The relationship between demographic characteristics and physical examination findings and recurrence in patients who} underwent component separation

\begin{tabular}{|l|l|l|l|}
\hline Patients & Recurrence & $\mathbf{n}$ & Mean \pm SD \\
\hline \multirow{2}{*}{ Gender } & No recurrence & 4 & $1.250 \pm 0.50$ \\
\hline Age & Recurrence & 26 & $1.461 \pm 0.50$ \\
\hline BMI & No recurrence & 4 & $3.250 \pm 0.50$ \\
\hline ASA score & Recurrence & 26 & $3.076 \pm 0.89$ \\
\hline HTD & No recurrence & 4 & $3.750 \pm 0.50$ \\
\hline BMI: body mass index, ASA: American Society of Anesthesiologists, HTD: hernia transverse diameter & $2.730 \pm 0.45$ \\
\hline & Recurrence & 26 & $3.500 \pm 0.57$ \\
\hline & No recurrence & 4 & $1.423 \pm 0.50$ \\
\hline & Recurrence & 26 & $2.750 \pm 0.50$ \\
\hline
\end{tabular}


Table 3. Relation between wound problem and recurrence in patients who underwent component separation

\begin{tabular}{|c|c|c|c|}
\hline \multicolumn{2}{|l|}{ Patients } & $n$ & p \\
\hline \multirow{2}{*}{ Patients with wound infection } & Recurrence & 3 & \multirow[t]{2}{*}{0.02} \\
\hline & No recurrence & 3 & \\
\hline \multirow{2}{*}{ Patients without wound infection } & Recurrence & 1 & \multirow[t]{2}{*}{0.121} \\
\hline & No recurrence & 23 & \\
\hline
\end{tabular}

female and 13 were male. The mean age of the patients was 54.8 years (range: 29-76). The mean BMI of the patients was 26.8 (range: 20.5-32.9). Mortality was not observed in any of the patients.

Gender, age, BMI, ASA scores, and hernia transverse diameter were separately grouped. No statistically significant relationship was found between age and gender and recurrence. There was a significant relationship between hernia transverse diameter, BMI level and ASA score and recurrence ( $p=0.02, p=0.03, p=0.00$, respectively) (Table 2).

Wound problems were observed in six of the 30 patients who underwent surgery with this technique, and recurrence was observed in three of these patients. Recurrence was observed in only one of the 24 patients who did not have any wound problems. The statistical evaluation revealed a $p$ value of 0.02 and recurrence was found to be statistically related with wound problems (Table 3).

\section{Discussion}

$\mathrm{IH}$ is the post-operative disruption of the integrity of the fascia that is closed and herniation of peritoneum from this defect (10). It develops in 2-23\% of abdominal operations (11-13). IH repair is a serious operation with mortality and morbidity, and a good pre-operative evaluation of the patient may reduce post-operative problems (13). In the repair of $\mathrm{IH}$, many methods are used, ranging from primary closure, mesh placement and closure with laparoscopic method. There are many studies in the literature related to these and primary closure can be performed in small defects, whereas mesh or CS is better in larger defects. CS was found to be superior to prosthetic material, but similar recurrence rates were determined after 24 months of follow-up (14). In the literature, recurrence rates have been reported between $0-28 \%$ in patients undergoing tension-free CS technique (15-16). In our study, this rate was found to be $13.3 \%$.

Wound complications are relatively common due to the formation of large wound surfaces. Hematoma and seroma formation are the most common complications. Infection rates are between $0-40 \%$ (17). In most cases, these complications can be treated conservatively. Similar complications were observed in our patients and one patient had severe wound problems. Although there was no statistically significant difference in the single randomized controlled study, more hematoma and seroma developed in the mesh group, and re-operation rates due to wound complications were significantly higher in the prosthetic mesh group. In the same study, no difference was found between using and not using mesh during CS in terms of hernia recurrence during 3 year follow-up (18). Attention should be paid to perforating vessels to reduce wound complications and to preserve vascularization of the skin (17). Laparoscopic approach is preferred by most surgeons because it allows for less general and wound complications, lower recurrence rates, shorter hospital stay and faster recovery (19).

The most important indicator of reliability in incisional hernia repair is recurrence. Most recurrences occur in the first 2 years, with recurrence risk for 10 years. The most common cause of recurrence is wound infection and other causes are obesity, COPD and surgical error (20). Recurrence occurred in four of 30 patients who underwent CS technique. There was a statistically significant correlation between recurrence and postoperative wound infection, obesity, hernia transverse diameter, and higher ASA scores. Attention can be paid to the use of drains to reduce the incidence of wound problems, thus recurrence rates (21). Obese patients need to be supported to lose weight and the skin vascularization should be protected as much as possible (22). There are publications reporting that wound infection is more common in obese patients (23). In our series, recurrence rate was found to be significantly higher in patients with high BMI.

\section{Conclusion}

We think that the CS technique can be safely applied in the repair of large incisional hernias by paying attention to wound infection.

Ethics Committee Approval: This study was started after the approval of the Istanbul Okmeydanı Training and Research Hospital Ethics Committee (decision no: 48670771-514.10).

Informed Consent: Informed consent was obtained from all patients.

Peer-review: Externally and internally peer-reviewed.

Author Contributions: Concept - U.A.; Design - U.A; Data Collection and/or Processing - U.A., T.B.; Analysis and/or Interpretation - U.A., T.B.; Literature Search - U.A., T.B.; Writing Manuscript - U.A., T.B.

Conflict of Interest: No conflict of interest was declared by the authors.

Financial Disclosure: The authors declared that this study received no financial support.

\section{References}

1. Van't Riet M, de Vos van Steenwijk PJ, Bonthuis F, Marquet RL, Steyerberg EW, Jeekel J, et al. Prevention of adhesion to prostetic mesh: comparison of barriers using an incisional hernia model. Ann Surg 2003; 237: 123-8.

2. Greenawalt KE, Butler TJ, Rowe EA, Finneral AC, Garlick DS, Burns JW. Evaluation of Sepramesh Biosurgical Composite in a Rabbit Hernia Repair Model. J Surg Res 2000; 94: 92-8.

3. Felemovicius I, Bonsack ME, Hagerman G, Delaney JP. Prevention of adhesions to polypropylene mesh. J Am Coll Surg 2004; 198: 543-8.

4. Kendall SW, Brennan TG, Guillou PJ. Suture length to wound length ratio and the integrity of midline and lateral paramedian incisions. Br J Surg 1991; 78: 705-7. 
5. Switzer NJ, Dykstra MA, Gill RS, Lim S, Lester E, de Gara C, et al. Endoscopic versus open component separation: systematic review and meta-analysis. Surg Endosc 2015; 29: 787-95.

6. Sayek I. 3. baskı Barış Tıp kitapevi, Ankara 2004. p. 1518.

7. Yahchouchy-Chouillard E, Aura T, Picone O, Etienne JC, Fingerhut A. Incisional Hernias I. Related Risk Factors. Dig Surg 2003; 20: 3-9.

8. Read RC. Development of inguinal herniorraphy. Surg Clin North Am 1984; 64: $185-96$

9. Ramirez OM, Ruas E, Dellon AL. "Components separation" method for closure of abdominal-wall defects: an anatomic and clinical study. Plast Reconstr Surg 1990; 86: 519-26.

10. Aksoy E, Çakmak A, Orozakunov E, Gürel M. Polipropilen meshlerin dokuya tespitinde kullanılan polipropilen dikiş, titanyum zımba ve nitinol çapa'nın kopma kuvvetlerinin karşılaştııılması. Ankara Üniversitesi Tıp Fakültesi Mecmuası 2009; 62: 39-43.

11. Skandalakis LJ, Gadacz TR, Mansberger AR, Mitchell WE, Colborn GL, Skandalakis JE. Modern Hernia Repair, The embryological and anatomical basis of Surgery. NewYork: Parthenon; 1996

12. Burger JWA, Luijendijk RW, Hop WCJ, Halm JA, Verdaasdonk EGG, Jeekel J. Long-term follow-up of a randomized controlled trial of suture versus mesh repair of incisional hernia. Ann Surg 2004; 240: 578-85.

13. Trivellini G, Bagni CM, Sollini A, Senni M, Leone S, Contessini Avesani E. Repair of giant hernias using more prosthesis. Hernia 2001; 5: 124-8.

14. de Vries Reilingh TS, van Goor H, Rosman C, Bemelmans MH, de Jong D, van Nieuwenhoven EJ, et al. Components separation technique for the repair of large abdominal wall hernias. J Am Coll Surg 2003; 196: 32-7.
15. Jernigan TW, Fabian TC, Croce MA, Moore N, Pritchard FE, Minard G, et al. Staged management of giant abdominal wall defects: acute and long-term results. Ann Surg 2003; 238: 349-55.

16. Sukkar SM, Dumanian GA, Szczerba SM, Tellez MG. Challenging abdominal wall defects. Am J Surg 2001; 181: 115-21.

17. LeBlanc KA, Booth WV, Whitaker JM, Bellanger DE. Laparoscopic incisional and ventral herniorrhaphy: our initial 100 patients. Am J Surg 2000; 180: 1937.

18. de Vries Reilingh TS, van Goor H, Charbon JA, Rosman C, Hesselink EJ, van der Wilt G], et al. Repair of giant midline abdominal wall hernias: "components separation technique" versus prosthetic repair: interim analysis of a randomized controlled trial. World J Surg 2007; 31: 756-63.

19. Iqbal CW, Pham TH, Joseph A, Mai J, Thompson GB, Sarr MG. Long-term outcome of 254 complex incisional hernia repairs using the modified RivesStoppa technique. World J Surg 2007; 31: 2398-404.

20. Cassar K, Munro A. Surgical treatment of incisional hernia. Brit J Surg 2002; 89: 534-45.

21. Vrijland WW, Jeekel J, Steyerberg EW, Den Hoed PT, Bonjer HJ. Intraperitoneal polypropylene mesh repair of incisional hernia is not associated with enterocutaneous fistula. Brit J Surg 2000; 87: 348-52.

22. Anthony T, Bergen PC, Kim LT, Henderson M, Fahey T, Rege RV, et al. Factor affecting recurrence following incisional hernioraphy. World J Surg 2000; 24 95-101.

23. Levi B, Zhang P, Lisiecki J, Terjimanian MN, Rinkinen J, Agarwal S, et al. Use of morphometric assessment of body composition to quantify risk of surgicalsite infection in patients undergoing component separation ventral hernia repair. Plast Reconstr Surg 2014; 133: 559-66. 